\title{
Article
}

\section{A study into compression ring dynamics using response surface methodology}

\author{
Dickinson, Matthew
}

Available at http://clok.uclan.ac.uk/18552/

Dickinson, Matthew ORCID: 0000-0001-6497-235X (2015) A study into compression ring dynamics using response surface methodology. International Journal of Passenger Cars - Mechanical Systems, 8 (1). pp. 92 94.

It is advisable to refer to the publisher's version if you intend to cite from the work. http://dx.doi.org/10.4271/2015-01-1335

For more information about UCLan's research in this area go to http://www.uclan.ac.uk/researchgroups/ and search for < name of research Group>.

For information about Research generally at UCLan please go to http://www.uclan.ac.uk/research/

All outputs in CLoK are protected by Intellectual Property Rights law, including Copyright law. Copyright, IPR and Moral Rights for the works on this site are retained by the individual authors and/or other copyright owners. Terms and conditions for use of this material are defined in the policies page.

\section{CLoK}

Central Lancashire online Knowledge www.clok.uclan.ac.uk

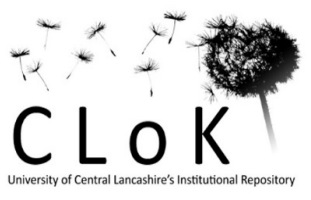


SAE had provided view-only access to this document to University-Central Lancashire for review/reference purposes only. This document is SAE-copyrighted intellectual property. It may not be shared, downloaded, duplicated, reprinted, or transmitted in any manner without prior written permission from SAE. SAE requires that you make best efforts to secure and protect the document from disclosure, taking at least the same care that you would for your own confidential information. Thank you. 


\title{
A Study into Compression Ring Dynamics using Response Surface Methodology
}

\author{
Matthew W. Dickinson, Nathalie Renevier, and John Calderbank \\ Univ. of Central Lancashire
}

\begin{abstract}
For decades the operational dynamics of the compression ring during operation, have been subject to debate $[\underline{1}, \underline{2}, \underline{3}, \underline{4}, \underline{5}, \underline{6}, \underline{7}]$. A complex computer simulation, using Design Of Experiments (DOE) methodology, was developed to study the effect of the compression ring rotation during running-in stages. Response Surface (RS) has been used to optimize ring displacement, as function of ring mass, width and radius. The optimised surface response has been compared to used compression rings and has shown a $2 \%$ variation between calculated and measured values.
\end{abstract}

CITATION: Dickinson, M., Renevier, N., and Calderbank, J., "A Study into Compression Ring Dynamics using Response Surface Methodology," SAE Int. J. Passeng. Cars - Mech. Syst. 8(1):2015, doi:10.4271/2015-01-1335.

\section{INTRODUCTION}

For almost two century's since the introduction of the split ring, there has been a considerable interest in the mechanics and dynamics of the piston rings in the combustion conditions $[\underline{8}, \underline{9}, \underline{10}, \underline{11}, \underline{12}]$. The four stroke engine that has been used for this study is a KTM 520. As this engine is a motorcycle engine this means, a high level of RPM can be obtained, this makes this an ideal selection for race condition research. To simulate the environment of running-in conditions the recommended running-in operational speed has been selected of $7,000 \mathrm{rpm}[\underline{13}]$. This paper presents simulation results from MatLab to display how the compression ring behaviours. In this work the ideal gas was used, a thermal and dynamic analysis was performed to enable an accurate behaviour representation. 3 sample sets of KTM BS-grade compression rings with MoS2 coatings were analysed after 60 mins of operation. Each ring was checked using a Quanta FEI Scanning Electron Microscope (SEM). Each image was cross analysed using open source software Gwyddion.

\section{SYSTEM}

The KTM 520 engine dimensions and material features have been reported in Table 1.

Table 1. showing component details

\begin{tabular}{|c|c|c|}
\hline Dimension [mm] & Component & Material \\
\hline 95 & $\begin{array}{l}\text { Compression } \\
\text { ring }\end{array}$ & $\begin{array}{l}\text { BS-Grade } \\
400 \text { grey }\end{array}$ \\
\hline 94.95 & Piston & $\begin{array}{l}\text { 4032-T6 } \\
\text { alloy }\end{array}$ \\
\hline 95 & Cylinder & Nikasil \\
\hline 115 & $\begin{array}{l}\text { Connecting } \\
\text { Rod }\end{array}$ & $\begin{array}{c}\text { UNS } \\
\text { C67400 }\end{array}$ \\
\hline 31 & Crank & $\begin{array}{l}\text { EN-30B } \\
\text { Alloy Steel }\end{array}$ \\
\hline
\end{tabular}

To calculate pressure and displacement of the piston during operation, equations noted by Stone were used [11]. Further modelling methods were used from work noted by Dickinson [ $\underline{4}]$.

To reduce the number of simulations, a centre composite, 3 factorial RS has been used to optimise the compression ring displacement. Factors such as radius, cross sectional width and the ring overall mass were studied.

Table 2. Factors for RS

\begin{tabular}{|lll|}
\hline Ring Width mm & Ring Rad mm & Ring Mass g \\
\hline $1-5$ & $30-50$ & $0.2-1.2$ \\
\hline
\end{tabular}

Table 2 shows the factors used in the RS. This produced a surface based on 20 runs, generating the RS graph.

\section{Surface Plot of RunOrder vs Ring Rad, Ring Width}

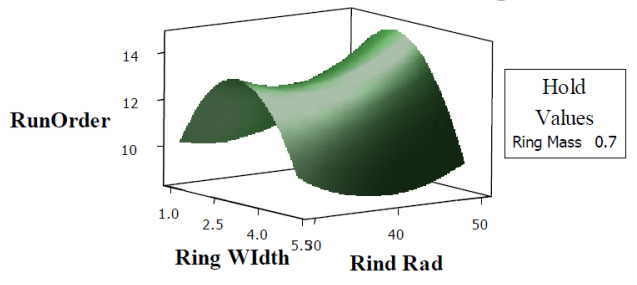

Figure 1. RS plot

Figure 1 shows the RS plot defined through the factorial set-up.

The defined variables are introduced into a Matlab/SimMechanics model. Each engine component is reengineered and defined within the SimMechanics system. The system is a G-Graphical interface to keep the system organised, where each major components are created with their own sub program (Figure 2). 


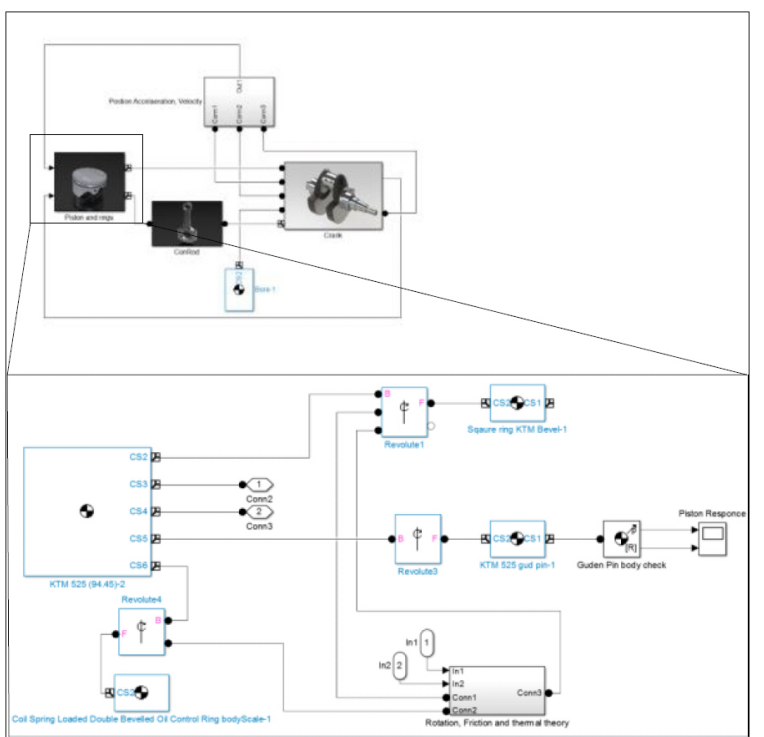

Figure 2. MatLab/SimMechanics model

Figure 2 shows the SimMechanics model used. The methodology used has been previously described $[\underline{2}, \underline{3}, \underline{4}]$.

To validate the simulation results, SEM images were taken of the top face of the compression ring to examine for scratches on the surface that would indicate ring rotation.

The displacement angle indicating ring displacement has been calculated using:

$$
\begin{gathered}
x=\tan ^{-1}\left(\frac{L}{R_{\text {rad }}}\right) \\
\boldsymbol{R}_{\text {rad }}=\boldsymbol{R}-\boldsymbol{D}
\end{gathered}
$$

Where $\mathrm{L}$ is the length of the measured scratch, $\mathrm{R}$ is the piston ring radius, $\mathrm{D}$ is the SEM observed image position from the outer radius of the ring.

\section{RESULTS}

Post processing of the data generated by the RS DOE shows a good correlation in the running order, as seen in Figure 3.

\section{Running Order best fit of tests}

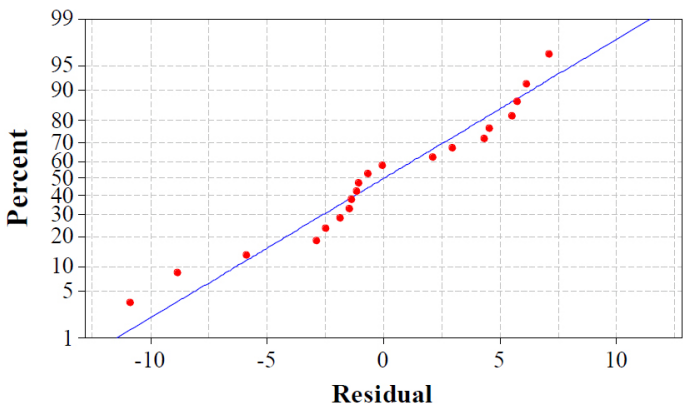

Figure 3. running order results best fit

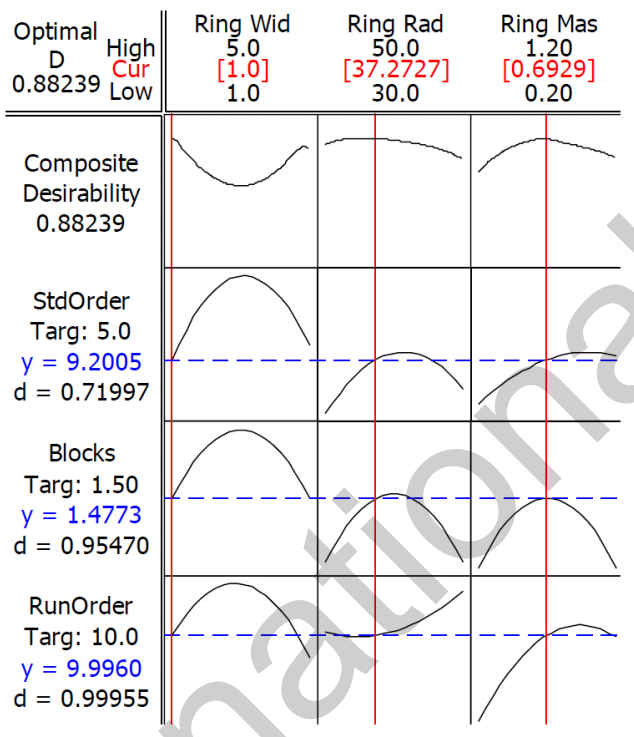

Figure 4. Running order of the optimised solution

The running order of the optimised solution (Table 3 ) is presented in Figure 4.

Table 3. Optimised solution

\begin{tabular}{|lll|}
\hline $\begin{array}{l}\text { Ring } \\
\text { Width } \\
(\text { RW) } \mathbf{~ m m}\end{array}$ & $\begin{array}{l}\text { Ring Rad (RR) } \\
\text { mm }\end{array}$ & $\begin{array}{l}\text { Ring Mass (RM) } \\
\text { g }\end{array}$ \\
\hline 1 & 37.27 & 0.69239 \\
\hline
\end{tabular}

Each goal for the StdOrder $=5$, Blocks $=1.5$ and Runorder $=10$. The composite desirability is 0.88239 .

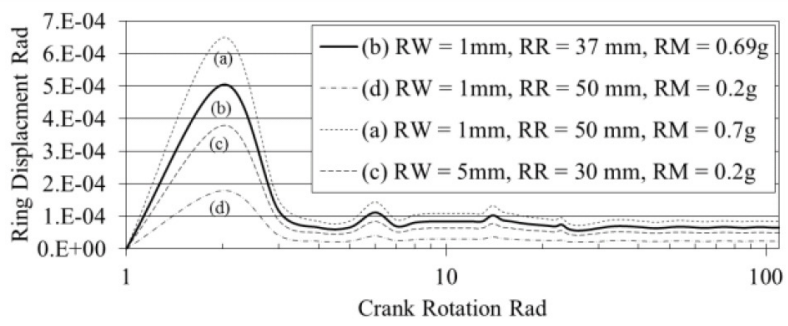

Figure 5. Ring displacement radius (b)

Figure 5 shows four representatives RS ring displacement radius outputs. Large oscillations are found below 10 radians of the crank rotation, with the factors defined, a second order system behaviour is seen. For the optimised solution (Table 3 ), the ring will rotate by a maximum of 0.005 rads. The result also indicates a resting time reached after 50 rads.

Figure 6 shows one of three samples images taken with SEM of the run-in KTM piston rings. Each image was measured for the maximum arc size relative to the ring radius. 


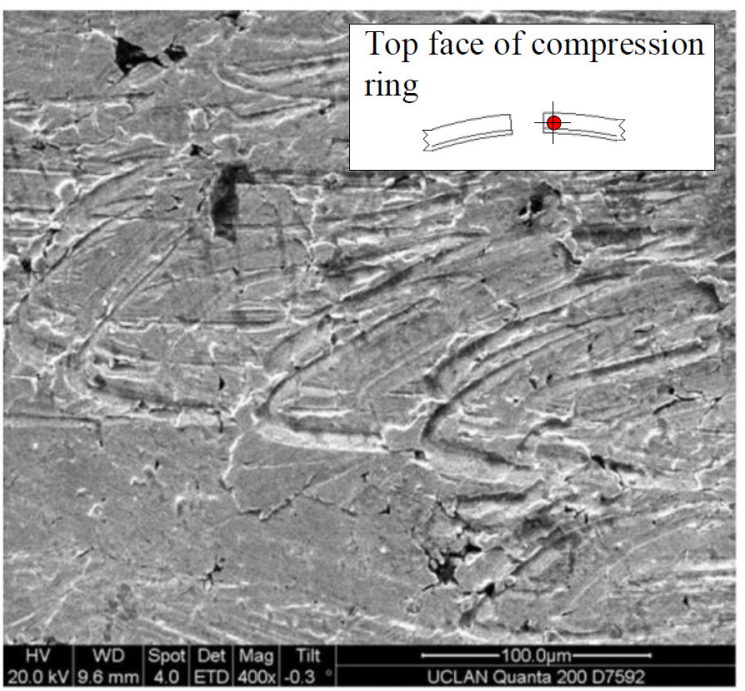

Figure 6. KTM 520 sample 1 top face

Table 4. Simulated against sample results

\begin{tabular}{|l|l|l|l|l|}
\hline $\begin{array}{l}\text { Sample } \\
\text { No. }\end{array}$ & $\begin{array}{l}\text { Sample } \\
\text { length }\end{array}$ & $\begin{array}{l}\text { Sample } \\
\text { max rad }\end{array}$ & $\begin{array}{l}\text { Figure 5 } \\
\text { max rad (b) }\end{array}$ & $\begin{array}{l}\text { Variati } \\
\text { on \% }\end{array}$ \\
\hline $\mathbf{1}$ & 0.0267 & 0.005656 & 0.005045 & 0.22 \\
\hline $\mathbf{2}$ & 0.0251 & 0.004986 & 0.005045 & 1.17 \\
\hline $\mathbf{3}$ & 0.0288 & 0.005133 & 0.005045 & 1.74 \\
\hline
\end{tabular}

Table 4 shows the results from RS optimized value (Table 3 ) and the measured values from the SEM images. The simulated system assumes a level of perfection in both material, combustion pressure and lubrication. Hence variations are recorded between the simulation and experimental data.

\section{DISCUSSION}

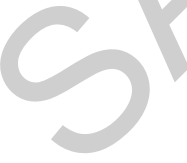

As the rotational momentum builds during operation, the highest levels of rotation are recorded in the first 20 radians of the crank rotation. Studies have been noted $[\underline{1}, \underline{3}, \underline{4}, \underline{14}, \underline{15}]$ that pistons rings might exhibit a continuous motion. However other work has been presented where little or no rotation has been observed $[\underline{16}, \underline{17}]$. However the validation work presented from the samples suggests that a large action of ration occurs over a small amount of crank rotation.

\section{CONCLUSION}

The compression ring will initially rotate and behave as a second order system. There is a good correlation between the experimental and the simulated results.
In an effort to optimise the rotation of the compression ring, it was originally thought that no rational would be the optimised value however results indicate that the must rotate regardless of the range of factors studied.

Further work will consider the effect of lubrication and also study the depths of the scratches.

\section{ACKNOWLEDGEMENTS}

I would like to thank Daniel Marfiewicz-Dickinson for suggestions of how to improve the paper.

\section{REFERENCES}

1. Brombolich L.J.. Structural Mechanics of Piston Rings. 1-34. 1993. St louis, MO, Compu-Tec Engineering, Inc (Internal Report).

2. Dickinson M., Renevier N., and Ahmed W.. The Refinement of the contact compression ring chamfer for race engine conditions. Comsol conference 2013. 5-9-2012

3. Dickinson, M., "Optimising Piston Ring Contact Face Chamfer for High Performance Engines," SAE Technical Paper 2013-01-0965, 2013, doi: $10.4271 / 2013-01-0965$.

4. Dickinson M., Renevier N., and Calderbank J.. A Study into the Compression Ring Rotation Based on Geometry. 1-4-2014.

5. Dowson D., International Journal of Mechanical Sciences 4 (2003) 159170.

6. Mittler R., Mierbach A., and Richardson D., ASME Conference Proceedings 2009 (2009) 721-735.

7. Priest M. and Taylor C.M., Wear 241 (2000) 193-203.

8. Miller G.M., Proceedings of the Institution of Mechanical Engineers 1847-1982 (vols 1-196) 13 (1862) 315-327.

9. Ramsbottom J., ARCHIVE: Proceedings of the Institution of Mechanical Engineers 1847-1982 (vols 1-196) 5 (1854) 70-74.

10. Smith E.H. and Arnell R.D., Tribol Lett 55 (2014) 315-328.

11. Stone, R., and Ball, J. K., "Automotive Engineering Fundamentals," (Society of Automotive Engineers, Inc., Warrendale, PA, doi:10.4271/R-199.

12. Taylor R.I., Brown M.A., and Thompson D.M., in: Tribology Series Lubricants and Lubrication - Proceedings of the 21th leeds-Lyon Symposium on Tribology, ed. Dowson D. (Elsevier, 1995).

13. Mather P., KTM EXC Enduros \& SX Motocross service \& repair manual: 2000 to 2007 (Haynes, 2007).

14. Heywood J., Internal combustion engine fundamentals (McGraw-Hill, Inc., 1988).

15. Tung S.C. and Huang Y., Tribology Transactions 47 (2004) 17-22.

16. Dunaevsky V. and Alexandrov S., Tribology Transactions 48 (2005) 108 118.

17. Heywood J., Internal combustion engine fundamentals (McGraw-Hill, Inc., 1988).

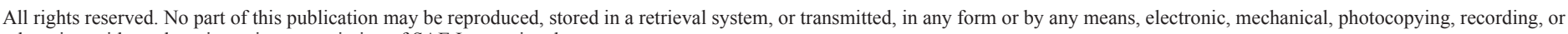
otherwise, without the prior written permission of SAE International. 